\author{
Carta ho Editor
}

\title{
Vitamin D supplementation in patients with rheumatic diseases - the process of making a meta-analysis, its adversities and learnings
}

\author{
Thiago Quadrante Freitas ${ }^{1}$, André Silva Franco ${ }^{1}$, Wanderley Marques Bernardo ${ }^{2}$, \\ Rosa Maria Rodrigues Pereira ${ }^{1}$
}

$\mathrm{N}$ umerous epidemiologic studies have linked vitamin $\mathrm{D}$ to rheumatic diseases. For example, people living near the equator have a lower risk of developing autoimmune conditions, probably due to more vitamin D synthesis in their $\operatorname{skin}^{1}$. A recent study ${ }^{2}$ illustrated this hypothesis by detecting a higher prevalence of autoantibodies and lower 25-OH vitamin D serum levels in a United States population when compared to a Sierra Leone population with the same genetic background. Furthermore, a seasonal variation in vitamin D synthesis by the skin has also been demonstrated, which may explain the seasonal increased risk of developing autoimmune diseases $^{3}$.

More recently, experimental studies began exploring new molecular actions of vitamin $\mathrm{D}$, which could physiologically link it to rheumatic conditions ${ }^{4}$. Recent in vitro and in vivo studies have shown an important immune modulatory effect by vitamin $\mathrm{D}$, which enhances innate immune activity ${ }^{5}$ and regulatory $\mathrm{T}$ cells ${ }^{6,7}$, while decreasing adaptive immune activity ${ }^{8}$, mainly Th17 and Th9 lymphocytes ${ }^{6,9,10}$, both involved in autoimmune disorders development ${ }^{10-12}$.
Such findings could provide a pathobiological explanation as to why there is so much evidence linking vitamin $\mathrm{D}$ to rheumatic diseases prevalence and activity. However, still little is known about clinical effects of vitamin D supplementation in patients with rheumatic diseases ${ }^{13}$.

Such conditions are very prevalent, affecting estimated 7 million Americans, 300 thousand of them being children ${ }^{14}$, with potential to severe sequelae and mainly decreased quality of life ${ }^{15,16}$. For example, when Systemic Lupus Erythematosus is active, it may course with kidney failure, myocarditis and seizures, which can lead to death, but also compromise short and long-term functionality and quality of life. Rheumatoid Arthritis, on the other hand, poses less life-threatening complications, but is one of the most limiting rheumatologic diseases ${ }^{17}$. It is also important to stress that accessible specific therapeutic targeting molecular structures are not available ${ }^{18}$.

Therefore, it would be interesting to verify if a simple, relatively cheap and safe therapy ${ }^{19}$, as vitamin D supplementation, could provide promising clinical outcomes as Lupus activity reduction, or improvement in

This study was supported by Fundação de Amparo à Pesquisa do Estado de São Paulo \#2016/08530-7.

1. Bone Metabolism Laboratory, Rheumatology Division, Faculdade de Medicina da Universidade de Sao Paulo - Sao Paulo, Brazil

2. Evidence-based Guidelines Developing - Brazilian Medical Association - Sao Paulo, Brazil.

Corresponding address: Av. Dr. Arnaldo, 455, 3rd floor, room 3193, Sao Paulo, SP, Brazil. 01246-903. E-mail: thiago.f@fm.usp.br 
Freitas TQ, et al. Vitamin D supplementation in patients with rheumatic diseases.

pain control for patients with Rheumatoid Arthritis.

In order to do this, randomized controlled trials that evaluated clinical and/or laboratorial outcomes after vitamin D supplementation in patients with rheumatic diseases were searched through five databases (MEDLINE, EMBASE, LILACS, COCHRANE, and CINAHL).

We concluded that the vast majority of studies is observational and still few randomized clinical trials evaluate clinical benefits of vitamin D supplementation; and the existing ones are not homogenous regarding intervention, length of supplementation, control groups and outcomes analyzed. Most of the studies also had a high risk of bias regarding a series of parameters.

Furthermore, some of them provided "preprocessed" data, instead of raw data, which made it impossible to compare to other studies and produce new

\section{REFERENCES}

1. Holick MF. Vitamin D: a millenium perspective. J Cell Biochem. 2003;88(2):296-307. doi: 10.1002/jcb.10338.

2. Gilkeson G, James J, Kamen D, Knackstedt T, Maggi D, Meyer A, et al. The United States to Africa lupus prevalence gradient revisited. Lupus. 2011;20(10):1095-103. doi: $10.1177 / 0961203311404915$.

3. Disanto G, Chaplin G, Morahan JM, Giovannoni G, Hypponen E, Ebers GC, et al. Month of birth, vitamin D and risk of immune-mediated disease: a case control study. BMC Med. 2012;10:69. doi: 10.1186/1741-7015-10-69.

4. Deluca HF, Cantorna MT. Vitamin D: its role and uses in immunology. FASEB J. 2001;15(14):2579-85. doi: 10.1096/ fj.01-0433rev.

5. Cantorna MT. Mechanisms underlying the effect of vitamin D on the immune system. Proc Nutr Soc. 2010;69(3):286-9. doi: $10.1017 / \mathrm{S} 0029665110001722$.

6. Joshi S, Pantalena L-C, Liu XK, Gaffen SL, Liu H, RohowskyKochan C, et al. 1,25-dihydroxyvitamin $\mathrm{D}(3)$ ameliorates Th17 autoimmunity via transcriptional modulation of interleukin-17A. Mol Cell Biol. 2011;31(17):3653-69. doi: 10.1128/MCB.05020-11.

7. Unger WWJ, Laban S, Kleijwegt FS, van der Slik AR, Roep BO. Induction of Treg by monocyte-derived DC modulated by vitamin $\mathrm{D} 3$ or dexamethasone: differential role for PDL1. Eur J Immunol. 2009;39(11):3147-59. doi: 10.1002/ eji.200839103.

8. Cantorna MT. Mechanisms underlying the effect of vitamin D on the immune system. Proc Nutr Soc. 2010;69(3):286-9. doi: $10.1017 / \mathrm{S} 0029665110001722$.

9. Lemire JM, Ince A, Takashima M. 1,25-Dihydroxyvitamin D3 attenuates the expression of experimental murine lupus of MRL/1 mice. Autoimmunity. 1992;12(2):143-8. doi: 10.3109/08916939209150321.

10. Garrett-Sinha LA, John S, Gaffen SL. IL-17 and the Th17 lineage in systemic lupus erythematosus. Curr Opin Rheumatol. 2008;20(5):519-25. doi: 10.1097/ BOR.0b013e328304b6b5.

Recebido: 22.12.2016

Aceito: 02.01.2017 numerical data, i.e., a meta-analysis.

Thus, the making of a systematic review and meta-analysis offers not only the knowledge about how to design and structure this kind of study, but it also matures the critical spirit regarding the design and data presentation of other types of studies, in order to contribute to the homogeneity of the knowledge, and to facilitate the compilation and comparison of statistical data. Furthermore, it can also help on preventing bias when designing a trial, which enhances its strength.

The objectives of this meta-analysis, then, were to provide a path to the making of novel clinical trials that could integrate the existing results and produce less biased and more robust evidence that corroborates our findings that vitamin D supplementation may decrease anti-dsDNA antibodies in Lupus and reduce Rheumatoid Arthritis recurrence.

11. Hsu H-C, Yang P, Wang J, Wu Q, Myers R, Chen J, et al. Interleukin 17-producing $\mathrm{T}$ helper cells and interleukin 17 orchestrate autoreactive germinal center development in autoimmune BXD2 mice. Nat Immunol. 2008;9(2):166-75. doi: $10.1038 /$ ni1552.

12. Matusevicius D, Kivisäkk P, He B, Kostulas N, Ozenci $\mathrm{V}$, Fredrikson $\mathrm{S}$, et al. Interleukin-17 mRNA expression in blood and CSF mononuclear cells is augmented in multiple sclerosis. Mult Scler. 1999;5(2):101-4. doi: $10.1177 / 135245859900500206$.

13. Abrahamsen B, Harvey NC. The role of vitamin D supplementation in patients with rheumatic diseases. Nat Rev Rheumatol. 2013;9(7):411-22. doi: 10.1038/ nrrheum.2013.71.

14. Helmick CG, Felson DT, Lawrence RC, Gabriel S, Hirsch R, Kwoh CK, et al. Estimates of the prevalence of arthritis and other rheumatic conditions in the United States. Part I. Arthritis Rheum. 2008;58(1):15-25. doi: 10.1002/art.23177.

15. Radner H, Yoshida K, Smolen JS, Solomon DH. Multimorbidity and rheumatic conditions-enhancing the concept of comorbidity. Nat Rev Rheumatol. 2014;10(4):2526. doi: 10.1038/nrrheum.2013.212.

16. Marsico A, Atzeni F, Piroddi A, Cazzola M, Stisi S, SarziPuttini P. Costs of pain in rheumatology. Reumatismo. 2014;66(1):103-7. doi: 10.4081/reumatismo.2014.771.

17. Wysocka-Skurska I, Sierakowska M, Kułak W. Evaluation of quality of life in chronic, progressing rheumatic diseases based on the example of osteoarthritis and rheumatoid arthritis. Clin Interv Aging. 2016;11:1741-50. doi: 10.2147/ CIA.S116185.

18. Péntek M, Poór G, Wiland P, Olejárová M, Brzosko M, Codreanu $\mathrm{C}$, et al. Biological therapy in inflammatory rheumatic diseases: issues in Central and Eastern European countries. Eur J Health Econ. 2014;15(Suppl 1):S35-43. doi: 10.1007/s10198-014-0592-6.

19. Cranney A, Horsley T, O'Donnell S, Weiler H, Puil L, Ooi $\mathrm{D}$, et al. Effectiveness and safety of vitamin $\mathrm{D}$ in relation to bone health. Evid Rep Technol Assess (Full Rep). 2007;(158):1-235. Available from: https://www.ncbi.nlm.nih. gov/pubmedhealth/PMH0023998/. 